\title{
RESEARCH ON THE RELATION BETWEEN THE PARTICLE SHAPE OF A COARSE AGGREGATE AND VOID CONTENT
}

\author{
RAZISKAVA KORELACIJE MED OBLIKO DELCEV GROBIH \\ AGREGATOV IN VSEBNOSTJO PRAZNIN
}

\author{
Xiao He, Jian Yin*, Jiewen Yang, Qiao Liang, Songyun Wu \\ School of Civil Engineering, Central South University of Forestry and Technology, no. 498 Shaoshan South Road, Tianxin District, \\ Changsha 410004, Hunan, China \\ Prejem rokopisa - received: 2018-08-28; sprejem za objavo - accepted for publication: 2018-10-18
}

doi:10.17222/mit.2018.187

\begin{abstract}
To quantitatively characterize the shape of coarse aggregates, a needle flake gauge meter was used to sieve coarse aggregates. The image technique was used to carry out the operations of edge recognition, greying and image binarization. Image-Pro Plus was employed to obtain the grain-shape parameters of the coarse aggregates, including sphericity and flatness. Tested void contents were obtained for the coarse aggregates so that the relationship between the shape parameters (sphericity, flatness) and the accumulated void content was analyzed. The results showed that the minimum values of sphericity and flatness were 0.67 and 1.01 while the maximum values were 0.88 and 1.9 , respectively. Sphericity was positively correlated with the void content of the coarse aggregate; on the contrary, flatness was negatively correlated with the void content. At the same condition of the mixture, compared to sphericity, flatness showed a higher correlation.

Keywords: coarse aggregate, particle shape, sphericity, flatness, void content
\end{abstract}

Avtorji so kvantitativno okarakterizirali obliko grobih agregatov s sejanjem le-teh na merilniku igličastih kosmičev. Uporabili so tehniko za obdelavo slike za razpoznavo robov, sivin in binarizacijo slike. Uporabili so programsko orodje za obdelavo slike Image-Pro-Plus, da so dobili parametre oblike zrn grobih agregatov vključno z okroglostjo in ploskostjo. Ugotovili so vsebnost praznin med grobimi agregati, in tako so lahko analizirali korelacijo med parametri oblike (okroglost in ploskost) in akumulirano vsebnostjo praznin. Rezultati analize so pokazali, da so minimalne vrednosti okroglosti in ploskosti $0,67,1,01$, in maksimalne vrednosti $0,88 \mathrm{oz}$. 1,9. Okroglost je bila pozitivno korelirana z vsebnostjo praznin grobih agregatov, medtem ko je nasprotno bila ploskost negativno korelirana $\mathrm{z}$ le-to. Istočasno $\mathrm{v}$ izbranih pogojih mešanja ploskost kaže višjo korelacijo $\mathrm{v}$ primerjavi z okroglostjo.

Ključne besede: grobi agregati, oblika delcev, okroglost, ploščatost, vsebnost praznin

\section{INTRODUCTION}

The characteristics of coarse aggregates are critically important as they affect the concrete performance. Coarse aggregates are the main components of concrete, accounting for $70-80 \%$ of the volume of concrete. Void content is generally used to optimize the aggregate gradation. ${ }^{1-4}$ Research has shown that the most economic type is the concrete, in which the coarse aggregates have the minimum void content or the maximum density. ${ }^{5-8}$ As the void content in coarse aggregates is reduced, the hardened concrete becomes denser and the strength increases. $^{9-12}$

Studies showed that the particle shape of coarse aggregates has a significant influence on the void content of concrete. ${ }^{13-15}$ However, the quantitative research of the shape characteristics of coarse aggregates was very limited. By employing various image techniques, two-dimensional and three-dimensional analyses of aggregate shapes were conducted. The technology of DIP was used to obtain the axial rate, roundness and sphericity of different graded coarse aggregates. The relationships

*Corresponding author e-mail:

csuyj700930@163.com (Jian Yin) among the three parameters were also analyzed. Similarly, the DIP technology was used to obtain the flatness, shape coefficient and elongation of coarse aggregates. Less research was done on the relation between the void content and the particle shape.

This study focuses on the methods for evaluating the particle shape, determining the linear relation between the void content and the shape, and identifying the impact on the concrete performance. We employed image techniques and image operations, such as edge recognition, greying and image binarization. Image-Pro Plus was used to determine the sizes of coarse aggregates. Sphericity and flat degrees were chosen as the indicators evaluating the relationship between the particle shape and the void content in concrete.

\section{EXPERIMENTAL PART}

\subsection{Raw materials}

Granite coarse aggregates were obtained from a quarry in Ningxiang, China. The properties of the aggregates and the aggregate gradation are shown in Table 1. 
X. HE et al.: RESEARCH ON THE RELATION BETWEEN THE PARTICLE SHAPE OF A COARSE AGGREGATE ...

Table 1: Gradation composition of the coarse aggregate

\begin{tabular}{|c|c|c|c|c|c|c|}
\hline \multirow{2}{*}{$\begin{array}{c}\text { Apparent } \\
\text { density } \\
\left(\mathrm{kg} / \mathrm{m}^{3}\right)\end{array}$} & \multirow{2}{*}{$\begin{array}{l}\text { Packing } \\
\text { density } \\
\left(\mathrm{kg} / \mathrm{m}^{3}\right)\end{array}$} & \multirow{2}{*}{$\begin{array}{l}\text { Silt } \\
\text { content } \\
(\%)\end{array}$} & \multicolumn{4}{|c|}{ Sieve screen residue $(\%)$} \\
\hline & & & $\begin{array}{l}4.75 \\
\mathrm{~mm}\end{array}$ & $\begin{array}{l}9.5 \\
\mathrm{~mm}\end{array}$ & $\begin{array}{l}16.0 \\
\mathrm{~mm}\end{array}$ & \\
\hline 2880 & 1570 & 0.7 & $100 \%$ & $90.0 \%$ & $37.3 \%$ & $12.8 \%$ \\
\hline
\end{tabular}

\subsection{Test methodologies}

\subsubsection{Void content of the coarse aggregate}

Four types of gradation were selected in this study. The single-grain grades included the particle sizes of (4.75-9.5, 9.5-16.0, 16.0-19.0 and 19.0-26.5) mm. We measured the loose accumulation void content of the single-grain grades. The method of determination was in line with GB/T 14685-2011 "pebble and crushed stone for construction". Equation (1) was used for the voidcontent calculation:

$$
V_{0}=\left(1-\frac{\rho_{1}}{\rho_{2}}\right) \times 100 \%
$$

where $V_{0}$ is the void content $(\%) ; \rho_{1}$ is the loose-bulk density $\left(\mathrm{kg} / \mathrm{m}^{3}\right) ; \rho_{2}$ is the apparent density $\left(\mathrm{kg} / \mathrm{m}^{3}\right)$.

\subsubsection{Aggregate-grain-shape measurement}

For the single gradation of coarse aggregates, sixty samples of the particles of each size were selected. We used the technology of image analysis; Photoshop was used to deal with the images, and the edge recognition, greying and binarization were conducted. Image-Pro Plus was then employed to measure the shape parameters. The relationships between the shape parameters and the void content were analyzed.

\section{RESULTS AND DISCUSSION}

\subsection{Grain-shape evaluation of coarse-aggregate parti- cles}

In the image analysis of coarse aggregates, aggregates are generally regarded as spheroids. Sphericity and flatness were selected as the indicators characterizing the

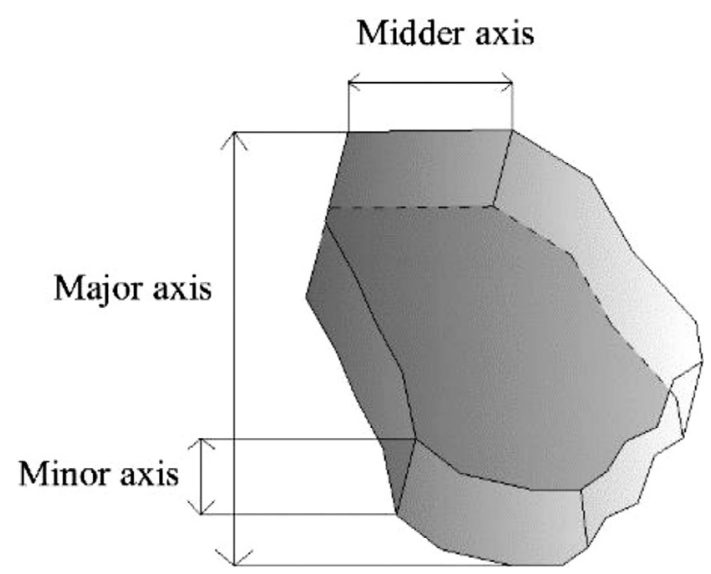

Figure 1: Three axes of particles aggregate shape. Figure 1 shows the three axes of a coarse aggregate.

To measure the shape of particles, in accordance with the three axes or external rectangular prism spindle of particles, the sphericity is calculated using Equation (2). The flatness is the ratio of thickness and width, obtained with the analysis of the particle shape. The flatness is calculated using Equation (3).

Sphericity $=\sqrt[3]{\frac{\text { middle axis } \times \text { minor axis }}{\text { major axis }^{2}}}$

Flatness $=\frac{\text { major axis }}{\text { minor axis }}$

After the procedures of edge recognition, greying and image binarization, the size of the coarse aggregates was obtained by employing Image-Pro Plus. The binary images of the coarse aggregates obtained with Photoshop are shown in Figure 2, and the measurement chart for the coarse aggregates created with Image-Pro Plus is shown in Figure 3. The length and width of the minimum circumscribed rectangle can be measured with Image-Pro Plus, and the thickness of a particle is also obtained. The size parameters of the coarse aggregates are shown in Table 2.

Table 2: Parameters of a part of a coarse aggregate measured with Image-Pro Plus software

\begin{tabular}{|c|c|c|c|c|c|}
\hline $\begin{array}{c}\text { Serial } \\
\text { number }\end{array}$ & $D_{\mathrm{L}}$ & $D_{\mathrm{i}}$ & $D_{\mathrm{S}}$ & Sphericity & Flatness \\
\hline 1 & 54.40 & 53.01 & 35.23 & 0.85 & 1.54 \\
\hline 2 & 57.13 & 49.89 & 47.48 & 0.89 & 1.20 \\
\hline 3 & 60.01 & 47.12 & 49.43 & 0.86 & 1.21 \\
\hline 4 & 48.01 & 47.85 & 29.87 & 0.85 & 1.60 \\
\hline 5 & 62.26 & 60.52 & 34.10 & 0.81 & 1.82 \\
\hline 6 & 65.05 & 58.31 & 47.32 & 0.86 & 1.37 \\
\hline
\end{tabular}

Comment: $D_{1}$ and $D_{2}$ are the length and width of the particle of the minimum circumscribed rectangle in front view, $D_{3}$ is the thickness of the particle in lateral view,

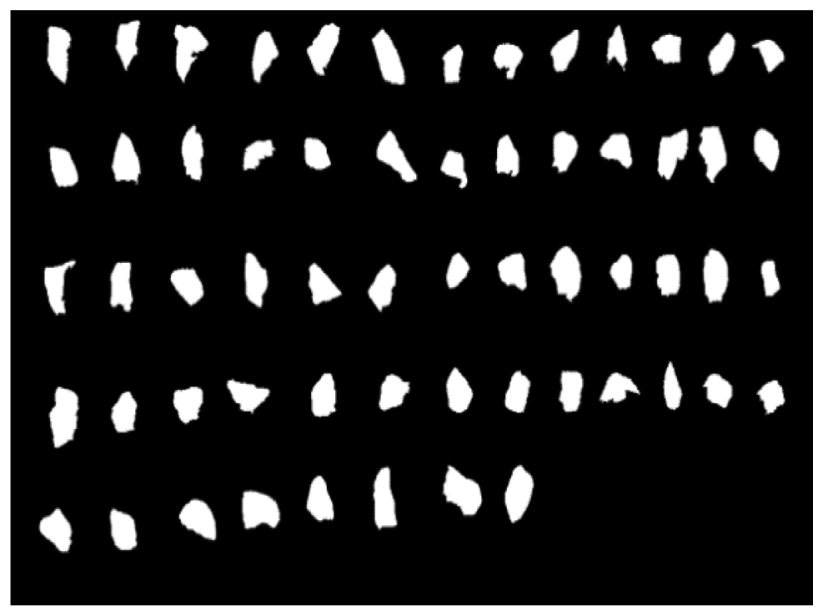

Figure 2: Binary image of a coarse aggregate 


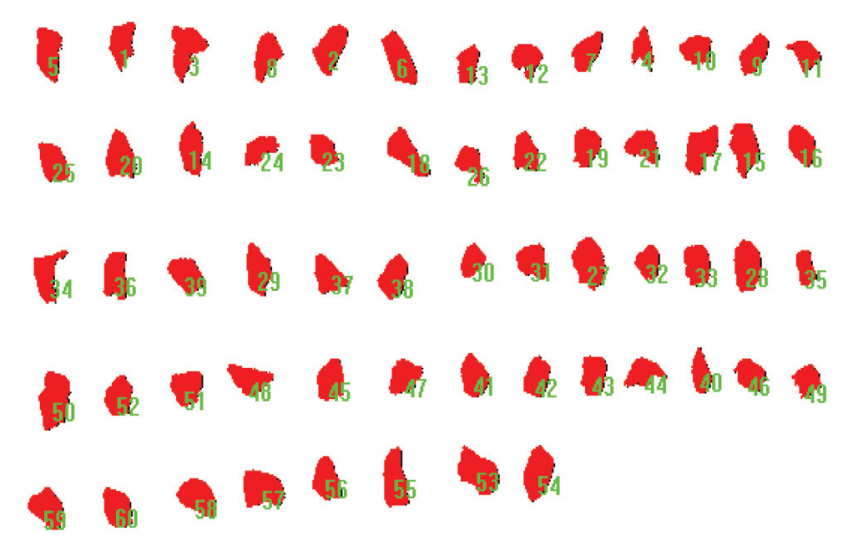

Figure 3: Measurement chart of a coarse aggregate

$D_{\mathrm{L}}=\operatorname{Max}\left(D_{1}, D_{2}, D_{3}\right), D_{\mathrm{s}}=\operatorname{Min}\left(D_{1}, D_{2}, D_{3}\right)$, the value of the median is $D_{\mathrm{i}}$.

Figures 4, 5, 6, 7 present the sphericity and flatness distributions of the particles whose gradations are (4.75-9.5, 9.5-16.0, 16.0-19.0 and 19.0-26.5) $\mathrm{mm}$. Figure 4a shows the value of the sphericity that was mainly concentrated at 0.79 , accounting for $11.29 \%$. The aggregates whose sphericity was above 0.79 accounted for $38.75 \%$, and the maximum value was 0.86 . Figure $\mathbf{4 b}$ presents the minimum value of the flatness, which was 1.07, accounting for $26.66 \%$. The maximum flatness was 1.2 , and the flatness that was below 1.2 accounted for $46.65 \%$.
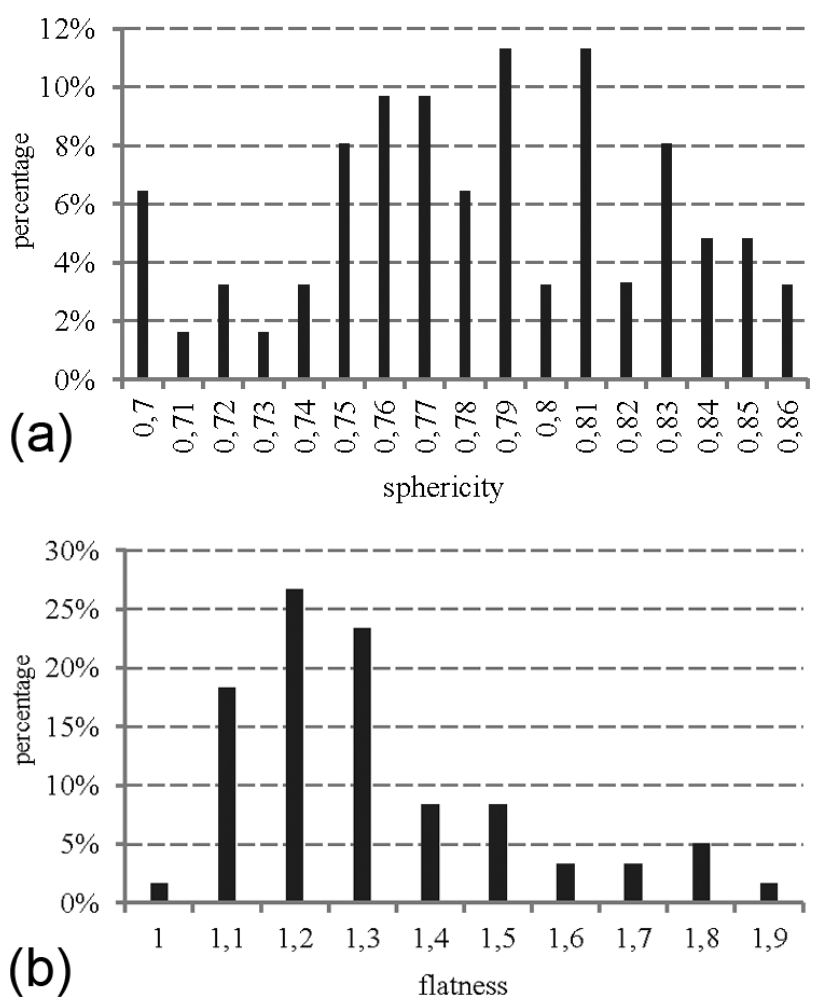

Figure 4: Distribution diagram for the coarse-aggregate size of $4.75-9.5 \mathrm{~mm}$
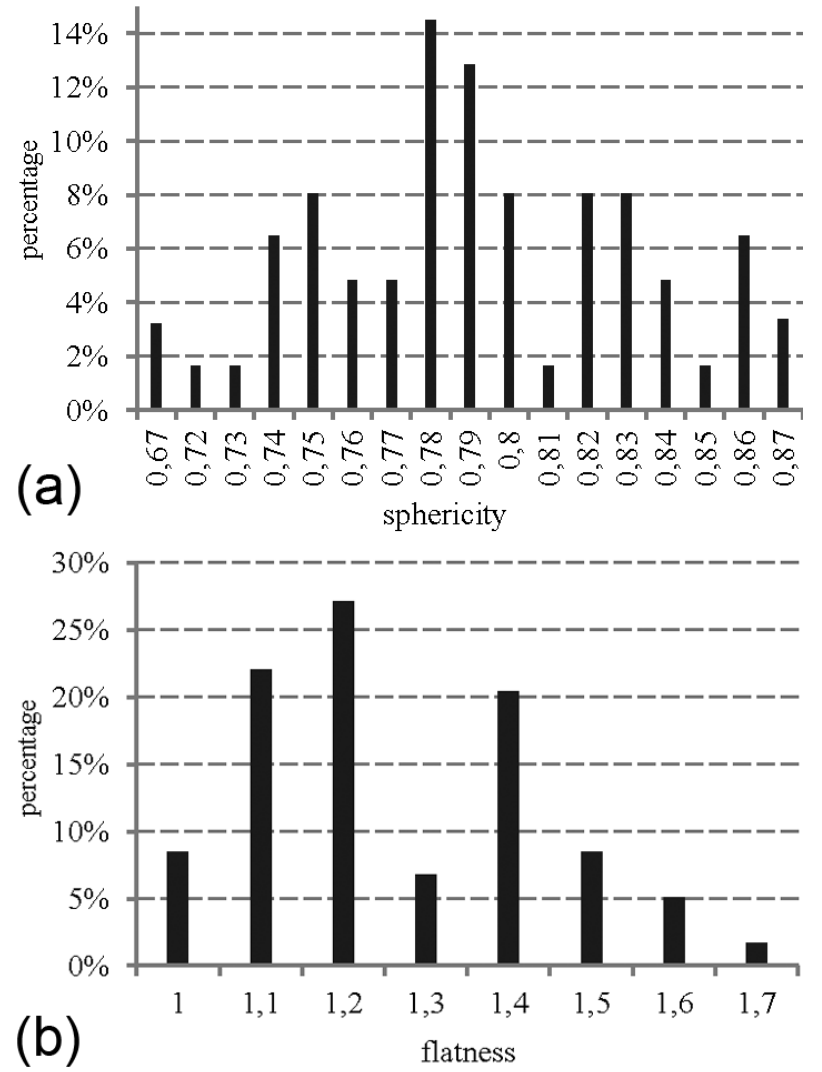

Figure 5: Distribution diagram for the coarse-aggregate size of $9.5-16.0 \mathrm{~mm}$
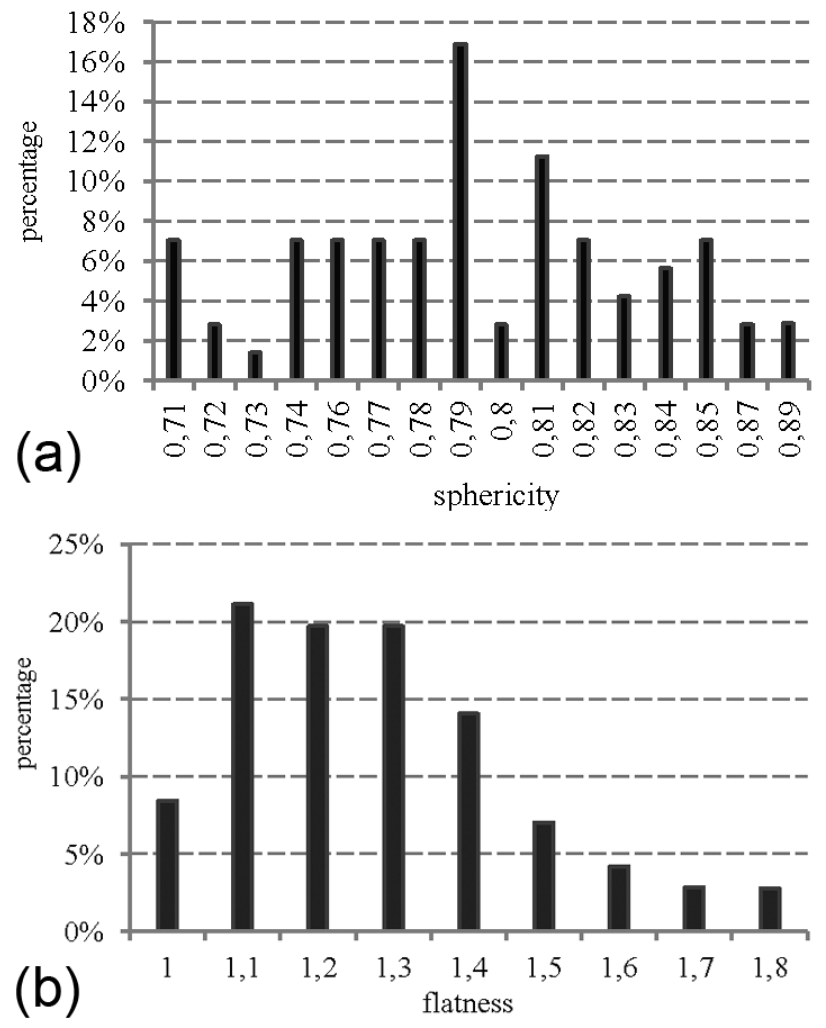

Figure 6: Distribution diagram for the coarse-aggregate size of $16.0-19.0 \mathrm{~mm}$ 
X. HE et al.: RESEARCH ON THE RELATION BETWEEN THE PARTICLE SHAPE OF A COARSE AGGREGATE ...
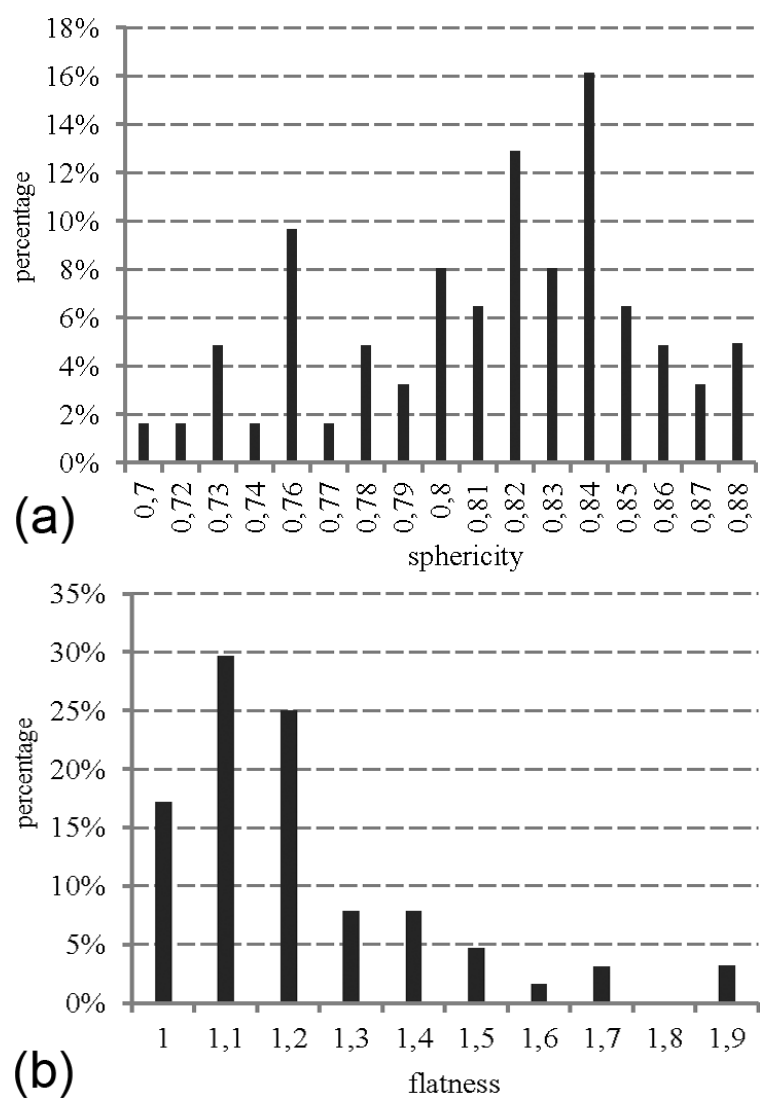

Figure 7: Distribution diagram for the coarse-aggregate size of $19.0-26.5 \mathrm{~mm}$

Figure 5a shows the value of the sphericity that was mainly concentrated at 0.78 , accounting for $14.80 \%$, and the values that were above 0.78 , accounting for $54.88 \%$. The maximum sphericity was 0.87 . Figure $\mathbf{5 b}$ presents the minimum flatness, which was 1.06 , accounting for $26.66 \%$. The value mainly concentrated at 1.2 accounted for $27.11 \%$. The aggregates with the flatness lower than 1.2 accounted for $57.61 \%$.

Figure 6a shows the particle sphericity that was mainly concentrated at 0.79 , accounting for $16.9 \%$. The values of the sphericity above 0.79 accounted for $43.69 \%$. The maximum sphericity was 0.89 . Figure $6 \mathbf{b}$ displays the minimum flatness of 1.01; the values mainly concentrated at 1.1 accounted for $21.12 \%$. The particle flatness below 1.1 accounted for $29.57 \%$.

Figure $7 \mathbf{a}$ shows the particle sphericity that was mainly concentrated at 0.84 , accounting for $16.12 \%$; the values of the sphericity above 0.84 accounted for $19.42 \%$. The maximum sphericity was 0.88 . Figure $7 \mathbf{b}$ presents the minimum flatness value of 1.03 . The values that were mainly concentrated at 1.1 accounted for $29.68 \%$, and the values of flatness below 1.1 accounted for $46.86 \%$.

\subsection{Results for the void content of the coarse aggregate}

The void contents of single-graded coarse aggregates are shown in Table 3. The minimum void content was
$46.1 \%$, obtained when the particle size of the coarse aggregate was $9.5-16.0 \mathrm{~mm}$. The sphericity and flatness of the aggregates with a size between $9.5-16.0 \mathrm{~mm}$ created a smaller void content compared with the aggregates with other gradations. The aggregate with a gradation of 19.0-26.5 $\mathrm{mm}$ showed the largest void content, which amounted to $48.6 \%$.

Table 3: Void contents of single-particle coarse aggregates

\begin{tabular}{|c|c|}
\hline Size of the coarse aggregate & Void content (\%) \\
\hline $4.75-9.5 \mathrm{~mm}$ & 46.6 \\
\hline $9.5-16.0 \mathrm{~mm}$ & 46.1 \\
\hline $16.0-19.0 \mathrm{~mm}$ & 47.9 \\
\hline $19.0-26.5 \mathrm{~mm}$ & 48.6 \\
\hline
\end{tabular}

\subsection{Relations between the grain shape and the void content}

Figure 8 shows the relationships between aggregate gradations and void contents. Linear regressions were performed and the equations were shown. Regression coefficients were all larger than 0.75 , indicating good linear relationships between the particle sphericity and void content. The flatness and void content also showed
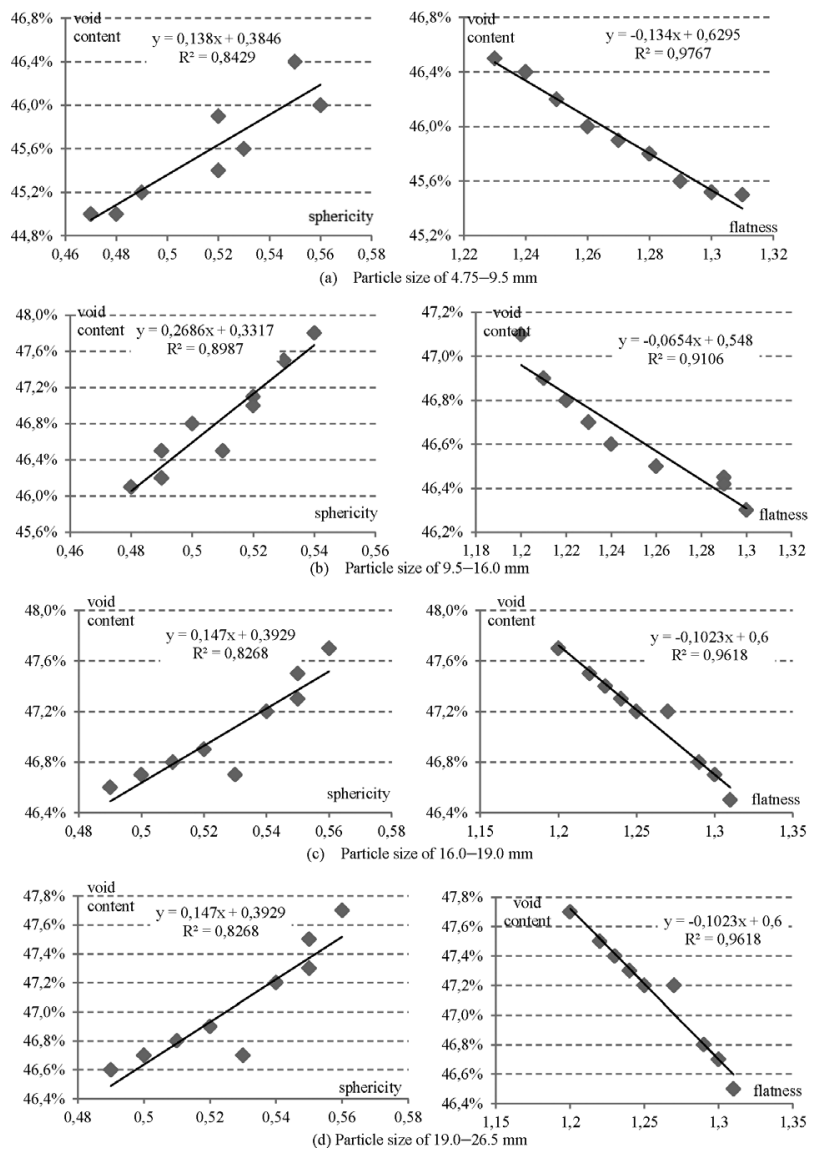

Figure 8: Linear-regression relations of the aggregate grain shape and void content: a) Particle size of $4.75-9.5 \mathrm{~mm}$, b) particle size of 9.5-16.0 $\mathrm{mm}$, c) particle size of $16.0-19.0 \mathrm{~mm}, \mathrm{~d}$ ) particle size of $19.0-26.5 \mathrm{~mm}$ 
a good linear relationship. However, in contrast with the sphericity, the larger regression coefficients of the equations that showed the relationship between the flatness and void content indicated a better linear dependence. Among these, the sphericity positively correlated with the void content, the larger value of sphericity and the larger value of void content. On the other hand, the flatness negatively correlated with the void content, the increase in the flatness and the void-content decreases.

\section{CONCLUSIONS}

Using image techniques, this study investigated the relationships between the particle-shape parameters and the void content in packed aggregates. Sphericity and flatness were selected as the indicators evaluating the characteristics of the particle shape. Image-Pro Plus was employed to carry out edge recognition, greying and image binarization. Aggregate shapes were analyzed with three-dimensional analyses, and their impact on the concrete performance was established. Based on the results from this study, the following conclusions can be drawn:

(1) For the particles with gradations of 4.75-9.5, $9.5-16.0,16.0-19.0$ and $19.0-26.5 \mathrm{~mm}$, the values of sphericity were mainly concentrated at $0.79,0.78,0.79$ and 0.84 , and the values of flatness were concentrated at $1.2,1.2,1.1$ and 1.1 .

(2) There was a positive linear relationship between the sphericity and void content. A larger value of sphericity led to a larger void content. Meanwhile, a negative linear relationship existed between the flatness and void content. A larger value of flatness led to a smaller void content.

(3) Regarding the sphericity and flatness, the correlation coefficient of flatness was greater than that of sphericity, indicating that flatness had a larger influence on the void content than sphericity.

\section{Acknowledgement}

This research was supported by the National Key R\&D Program of China (no. 2016YFC0700801-01), Scientific Innovation Fund for Post-Graduates of Central South University of Forestry and Technology (no. 20181006).

\section{REFERENCES}

${ }^{1}$ L. P. Esteves, P. B. Cachim, V. M. Ferreira, Effect of fine aggregate on the rheology properties of high performance cement-silica systems, Constr. Build. Mater., 24 (2010), 640-649, doi:10.1016/ j.conbuildmat.2009.11.005

${ }^{2}$ S. T. Erdogan, P. N. Quiroga, D. W. Fowler, Three-dimensional shape analysis of coarse aggregates: New techniques for and preliminary results on several different coarse aggregates and reference rocks, Cem. Concr. Res., 36 (2006), 1619-1627, doi:10.1016/ j.cemconres.2006.04.003

${ }^{3}$ S. Akbulut, Fractal dimensioning of sand grains using image analysis system, J. Eng. Sci., 8 (2002) 329-334

${ }^{4}$ T. Al-Rousan, E. Masad, E. Tutumluer, T. Pan, Evaluation of image analysis techniques for quantifying aggregate shape characteristics, Constr. Build. Mater., 21 (2007), 978-990, doi:10.1016/ j.conbuildmat.2006.03.005

${ }^{5}$ S. Arasan, A. S. Hasiloglu, S. Akbulut, Shape properties of nature and crushed aggregate using image analysis, Int. J. Civil Str. Eng., 86 (2012), 535-539

${ }^{6}$ C. Chen, C. Gao, L. Zhuang, X. Li, P. Wu, A Many-body dissipative particle dynamics study of spontaneous capillary imbibition and drainage, Langm. ACS J. Surf. Coll., 26 (2010) 9533-9538, doi:10.1021/la100105f

${ }^{7}$ J. S. Chen, M. K. Chang, K. Y. Lin, Influence of coarse aggregate shape on the strength of asphalt concrete mixtures, J. East. Asia Soc. Transp. Stud., 6 (2005), 1062-1075

${ }^{8}$ B. X. Li, W. Wei, M. Y. Chen, Isometric ratio, roundness and sphericity of coarse aggregates and their relationship, J. Build. Mater., 18 (2015), 532-536, doi:10.3969/j.issn.1007-9629.2015.04.001

${ }^{9}$ H. F. Liu, H. Li, Aggregate model of concrete dynamic performance based on random numerical simulation, Chin. J. Appl. Mech., 1 (2017) 34, 162-167

${ }^{10}$ Y. Liu, Z. P. You, Discrete-element modeling: Impacts of aggregate sphericity, orientation, and angularity on creep stiffness of idealized asphalt mixtures, J. Eng. Mech., 137 (2011), 294-303, doi:10.1061/(ASCE)EM.1943-7889.0000228

${ }^{11}$ I. B. Muhit, S. Haque, M. R. Alam, Influence of crushed coarse aggregates on properties of concrete, Am. J. Civ. Eng. Arch., 1 (2013), 103-106, doi:10.12691/ajcea-1-5-3

${ }^{12}$ M. B. Mgangira, J. K. Anochie-Boateng, J. Komba, Quantification of aggregate grain shape characteristics using 3-D laser scanning technology, Cha. Agg., 7 (2013), 23-35

${ }^{13}$ M. M. T. Thwin, T. S. Quah, Application of neural networks for software quality prediction using object-oriented metrics, J. Syst. Softw., 76 (2005), 147-156, doi:10.1016/j.jss.2004.05.001

${ }^{14}$ C. J. Zega, Y. A. Villagran-Zaccardi, A. A. D. Maio, Effect of natural coarse aggregate type on the physical and mechanical properties of recycled coarse aggregates, Mater. Str., 43 (2010), 1195-202, doi:10.1617/s11527-009-9480-4

${ }^{15}$ Q. Xiong, X. D. Wang, L. Zhang, Research summary of digital image processing technology on coarse aggregate morphology characteristics, Subg. Eng., 1 (2012), 7-9 